\title{
Social Representations about HIVIAIDS Built by the Elderly: an Integrative Review \\ REVIEW
}

\begin{abstract}
Olívia Galvão Lucena Ferreira', Antonia Oliveira Silva², Alinne Beserra de Lucena Marcolino', Tatyana Ataíde Melo de Pinho', Laura de Sousa Gomes Veloso ${ }^{3}$, Jordana de Almeida Nogueira ${ }^{4}$, Eliane de Sousa Leite ${ }^{5}$, Maria Adelaide Silva Paredes Moreira ${ }^{6}$
\end{abstract}

\section{Abstract}

Introduction: The theory of social representations possible to know with more particularity how individuals see the reality facing the object/phenomenon from their experiences that are loaded with beliefs and values and guide their conduct.

Objective: Collect studies about the social representations of HIV/ AIDS built by the elderly.

Method: An integrative literature review that sought national and international articles in the databases: LILACS, SciELO and PUBMED, with time frame from 2005 to 2014.

Results: We selected and analyzed six articles identifying four thematic groups that served as the discussion guide: HIVIAIDS and the biopsychosocial difficulties; Aging and HIVIAIDS: a double challenge; HIVIAIDS and ways of coping; Vulnerability to HIVIAIDS.

Discussion: It can be observed that the social representations about HIVIAIDS built by elderly showed that the beliefs, interpretations and network developed symbolizations are complex, permeated by the disease and its biopsychosocial consequences. However, it turns out that, despite the complexity of the phenomenon experienced, people look for ways of coping, in order to improve their quality of life and leave it as close as possible to what it was before the diagnosis.

Conclusion: It turns out that, despite the complexity of the phenomenon experienced, people look for ways of coping, in order to improve their quality of life and leave it as close as possible to what it was before the diagnosis.
1 Physiotherapist, Doctoral Student of Nursing at the Federal University of Paraiba. João Pessoa, Paraiba, Brazil.

2 Nurse, PhD in Psychology at the Institute of Labor Science and Enterprise - ISCTE, Lisbon, Portugal, Professor of Nursing at the Federal University of Paraiba. João Pessoa, Paraiba, Brazil.

3 Physiotherapist, Master's Student of Nursing at the Federal University of Paraiba. João Pessoa, Paraiba, Brazil.

4 Nurse, Doctorate in Nursing and Public Health from Ribeirão Preto School of Nursing, University of São Paulo, Professor of the Postgraduate Nursing Program at the Federal University of Paraiba. João Pessoa, Paraiba, Brazil.

5 Nurse, Doctoral Student of Nursing at the Federal University of Paraiba. João Pessoa, Paraiba, Brazil.

6 Physiotherapist, Doctorate in Health Sciences, Federal University of Rio Grande do Norte, Professor at the Federal University of Paraiba. João Pessoa, Paraiba, Brazil.

\section{Contact information:}

Eliane de Sousa Leite.

” elianeleitesousa@yahoo.com.br

\section{Keywords}

Knowledge; HIV; Elderly; Nursing. 


\section{Introduction}

The increase in life expectancy in recent decades has resulted in an accelerated process of population aging. It is estimated that people over 59 now account for $11 \%$ of the global population, and this percentage is expected to increase to $16.5 \%$ in 2030. In Brazil, in 2012, estimates indicate that the proportion of the total population over the age of 59 years old is approximately of $11.3 \%$ (22 million people) and this figure will double in the next 20 years. It also has been observed increased incidence of some diseases that were not so common in this age group, such as AIDS [1].

The increase in the number of AIDS cases in older people happens not only in Brazil but in countries around the world. The first case of AIDS in Brazil was notified in 1980 and the first case of this disease in individuals over age 50 were reported in 1982, since then, there has seen an increase in the incidence of AIDS in the population over 50 years old and the incidence doubled between the years 1996 to 2006 [1-2].

The number of AIDS cases in Brazil, mainly in the northeast, can be much greater than it is believed due to the occurrence of underreporting. And this disease in the elderly population presents epidemiological significance, not the absolute numbers but the incidence rates, prevalence, mortality and potential years of life lost, estimated at up to 15 years [3].

Although people living with HIVIAIDS have been benefited with the advances in technology and health care, prolonging their expectations facing life to the disease, people over the age of 50 years old and above, with low education when HIV-infected, have the effect of immunosuppression more intensely than younger people because it adds to the effects of AIDS diseases other characteristics of this age group [4].

AIDS must be considered as well as a biological phenomenon as a social phenomenon, because it involves issues related to sexuality, conjugal morality and drug use, whose proportions are capable of causing impact on moral principles, religious and ethical on the personal conduct and procedures in public health. However, HIV infection and AIDS in the elderly is still a little discussed topic, as well as sexuality in old age is still a subject neglected by society, by health professionals and by older people themselves [5].

Studies indicate that there are divergent conceptions of elderly behavior living with HIVIAIDS. Noting the correlation of senility a decrease in sexual practices, which are attributed to heterosexuality and monogamy, looking almost impossible for society to an elderly person acquires HIVIAIDS [6].

Currently it has been observed that the HIVIAIDS virus has spread randomly among the population considered vulnerable and this spread is associated with risky behavior. Studies on how people perceive the risk of HIV infection show that the investigation of perceived risk alone is not enough to motivate behavior or attitude change. So look for other forms of research and theories that seek to explain the phenomena that favor a further and deeper understanding, becoming relevant to propose protection strategies to health more assertive [7-8].

Definitely, attitudes and knowledge of the elderly population seems to be less sensitive compared to other age groups and this can be attributed to the small number of targeted prevention programs for the elderly and low levels of comfort to the doctor with geriatric patients to discuss about sexuality [9].

Despite the growing recognition of the need for prevention interventions targeting HIV-positive individuals, prevention interventions to older adult HIVpositive are still scarce. Efforts to target high-risk sexual behaviors may be even more critical in the older population because of sociocultural, biological and behavioralvulnerabilities [10].

Thus, recognizing what older people think about HIVIAIDS or as aopinion in relation to this disease 
provides an understanding of coping behaviors that are influenced by beliefs, attitudes and values culturally constructed and shared by a particular group. In this context the theory of social representations have significant contribution to the understanding of various objects/phenomena, especially in the health sector, being an important reference in the study of HIV/AIDS and aging [11-12].

The social representation as a form of practical knowledge that act as mediators between subject and object, in the social interactional context has been defined as "a set of concepts, propositions and explanations created in everyday life during the inter-communication. This is equivalent to myths and belief systems of traditional societies and can still be seen as a contemporary version of common sense" [13].

Consequently, from the theory of social representations it is possible to know with more particularity how people see the reality facing the object/phenomenon from their experiences that are loaded with beliefs and values and guide their conduct. This theory being useful in guiding health practices and the implementation of actions that promote ways to prevent or care for thepeople [4].

Thus, the formation of social representations happens through two processes: objectification and anchoring. Regarding the process of objectification, this occurs through three stages: the first concerns the decontextualization of information through normative and cultural criteria; the second occurs in the formation of a figurative core, creating a structure that plays figuratively a conceptual framework; and the last step, naturalization, ie, processing of these images in reality elements. Thus, the objectification process materializes ideas and concepts in a figurative core or a structural layout causes to become effective a conceptual layout with which give an image, a material contrast, result has, firstly, cognitive flexibility [14].

The anchoring process is to classify and name something strange; it is compared to a paradigm of a category thought of as appropriate in order to allow the strange be interpreted and establishes a positive or negative relation to him [4].

In this sense, research on the social representations of HIV/AIDS for older people allow contact with content and images that express, in a way, their needs, which is important for planning actions that provide the solvability of these needs whether they are biological, psychological or social.

This study becomes relevant for gathering studies that address how older people think about HIV/ AIDS that circulate knowledge and how they deal and act to live with the disease in a particular sociocultural context. Therefore, this research aims to analyzing the scientific literature about the social representations of HIVIAIDS built by older people in the period between 2005-2014.

\section{Method}

This is an integrative review, with a qualitative approach, regarding the social representation of HIV/ AIDS for older people seeking to answer the following guiding question: "What are the social representations of HIVIAIDS built by older people found in scientific production in the last ten years?"

The integrative review aims to summarize several published studies, in a systematic way, enabling general conclusions about a particular topic, contributing to the deepening of knowledge of the subject investigated and pointing gaps in the research carried that need to be filled with the performance of new studies [15].

For this study the following methodological steps were taken: theme of identifying and guiding question; sample selection from the establishment of the inclusion and exclusion criteria; characterization of selected studies; evaluation, interpretation and discussion of the results; ending with the presentation of the review.

To answer the research question, it sought to items available in national and international jour- 
nals indexed in Virtual Health Library (BVS) in the following databases: Latin American and Caribbean Health Sciences (LILACS), Scientific Electronic Library Online (SciELO) and Biomedical Literature Citattions and Abstracts - North American (PUBMED), with time frame 2005-2014.

To conduct the literature available, descriptors were selected in the list Health Science Descriptors/ Medical Subject Headings (MeSH), namely "social representations"; "HIV"; "Elderly". They were considered as inclusion criteria: articles published in the last ten years; publications that used the theoretical framework of social representations for understanding the phenomenon studied; studies about social representations of HIVIAIDS built by older people; publications available in Portuguese and English. Review articles were excluded and the publications that were not in scientific paper format, such as books, theses, dissertations, book reviews, letters and editorials.

Data were collected from the following combination of descriptors in Portuguese: "social representations" AND "HIV" AND "old"; "Social representations" AND "HIV" AND "elderly", finding 09 articles in LILACS, 28 in PUBMED and 33 in SCIELO, totaling 70 titles, as described below (Figure 1)

The next phase, a close reading of selected articles was made in order to locate studies that addressed the issue in question. At this stage there were excluded duplicate or studies that did not meet the inclusion criteria listed above. After applying the inclusion and exclusion criteria, the corpus consisted of 06 items, which were read and cataloged according to a statement which summarizes their general attributes.

Authors and data publication referring to the publication were identified: year, journal, research site, language, purpose of the study, methodology applied (study participants, type of study, collection instrument and data analysis) and main results, facilitating the analysis of the studies. The results were organized in order to emphasize the contents of the social representations of HIVIAIDS in older people, summarizing the main findings of the publications in relation to the subject studied, seeking to outline intervention prospects and future researches.

Figure 1: Explanatory publications selection flowchart. João Pessoa, Paraíba, 2015.

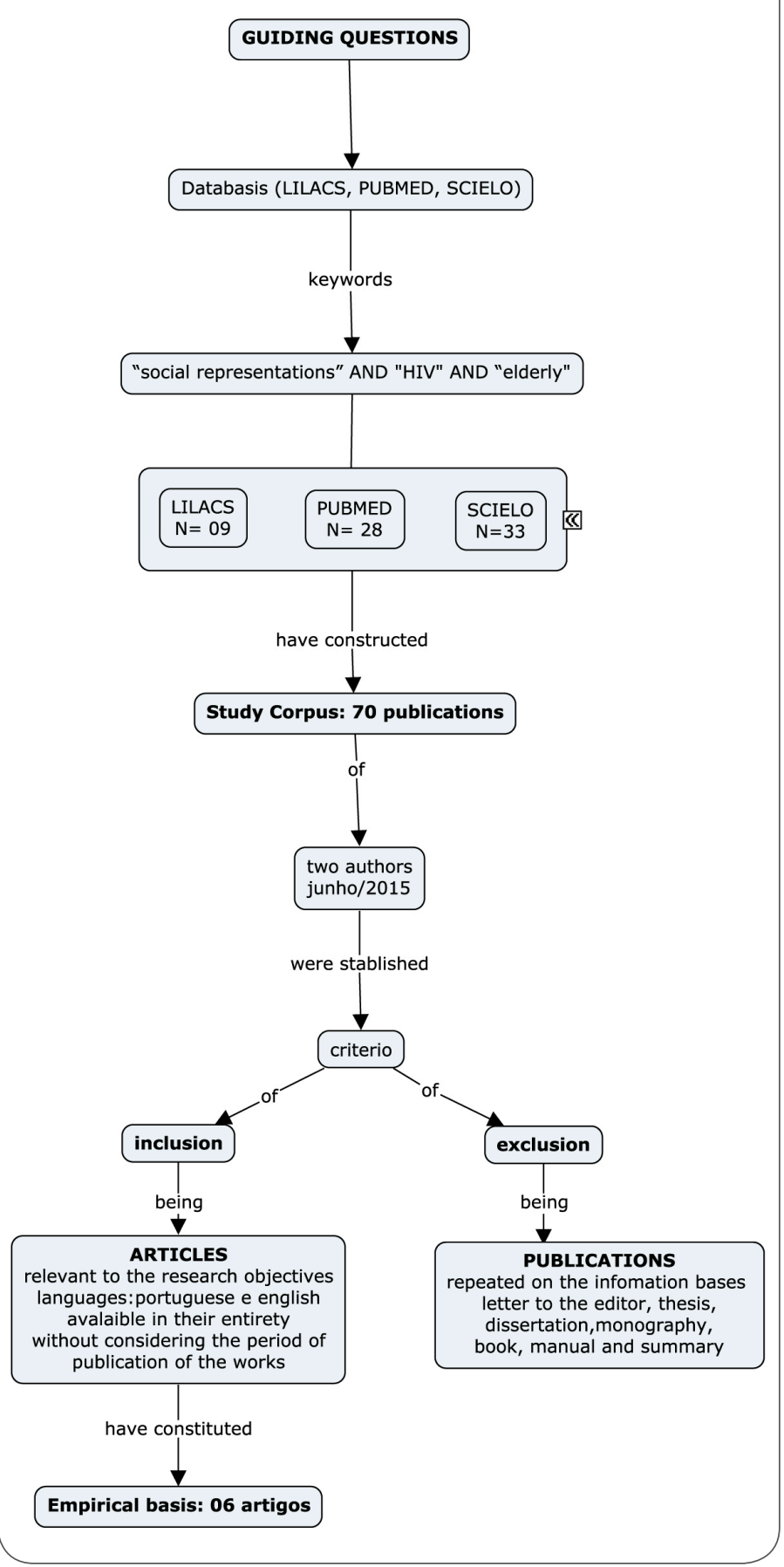




\section{Results}

The articles selected for the sample were published between the years 2006 to 2011. All studies were conducted in Brazil, 03 studies in the State of Paraiba, 02 studies in Rio de Janeiro and 01 study conducted in the State of Goias. The research had the participation of older people whose sample size ranged from 09 to 247 subjects. There were used for data collection, interviews, questionnaires and free association of words test (TALP), the interview collection method most used data and the data resulting from these instruments have been exploited through thematic content analysis technique, where one of the studies used the Alceste software and two of them carried out factor analysis of correspondence with the aid of the Tri-Deux-Mots software. For a better view of the selected studies, it was organized a synoptic table.

\section{(Table 1)}

To guide the discussion there were identified four thematic groups regarding the social representations about HIVIAIDS for elderly people: (1) HIVIAIDS and the biopsychosocial difficulties; (2) aging and HIV/ AIDS: a double challenge; (3) HIVIAIDS and ways of coping; (4) vulnerability to HIVIAIDS.

\section{Discussion}

It was observed during the search for articles, the research on the social representation of HIVIAIDS are mostly directed at adolescents, youth and young adults; however, for the elderly that number becomes very restricted. All studies included in this research were conducted in Brazil, realizing that the theory of social representations has funded many studies in the country to the understanding of various phenomena, especially in the health field.

The theory of social representations has shown the methodological plurality, thematic and conceptual, not only in social psychology, but also in many applied fields, such as health and education, proving to be useful in understanding complex psychosocial phenomena. Through this theory it can understand common sense, where the object/phenomenon is built and shared by a group during conversations and relationships in daily life [16].

Emerged from the results of studies four categories on the social representation of HIVIAIDS built for elderly people who are discussed below:

\section{HIV/AIDS and the biopsychosocial difficulties}

Social representations about HIVIAIDS built by the elderly who live with the disease were centered, not

Table 1. Studies on social representations about HIVIAIDS for elderly people, in the period from 2005 to $2014(n=6)$.

\begin{tabular}{|c|c|c|c|c|c|}
\hline Authors & Year & Journal & Sample (n) & Instrument & Data Analysis \\
\hline Brazilian et al. & 2006 & $\begin{array}{l}\text { Rev Latino-am } \\
\text { Enfermagem }\end{array}$ & 9 & Interview & ContentAnalysis \\
\hline Saldanha et al. & 2008 & Psico-USF & 20 & $\begin{array}{l}\text { Questionnaire; } \\
\text { TALP }\end{array}$ & $\begin{array}{l}\text { Descriptive statistics; Factorial analysis } \\
\text { of correspondence (Tri-Deux-Mots); }\end{array}$ \\
\hline Saldanha et al. & 2009 & $\begin{array}{l}\text { Inter-American Journal of } \\
\text { Psychology }\end{array}$ & 21 & $\begin{array}{l}\text { Interview; } \\
\text { TALP }\end{array}$ & $\begin{array}{l}\text { Factorial Analysis of Correspondence } \\
\text { (Tri-Deux-Mots); } \\
\text { ContentAnalysis }\end{array}$ \\
\hline Lima et al. & 2010 & $\begin{array}{l}\text { R. pesq.: cuid. fundam. } \\
\text { Online }\end{array}$ & 20 & Interview & ContentAnalysis \\
\hline Oliveira et al. & 2011 & Rev. enferm. UERJ & 20 & Interview & ContentAnalysis \\
\hline Torres et al. & 2011 & $\begin{array}{l}\text { R. pesq.: cuid. fundam. } \\
\text { Online }\end{array}$ & 247 & $\begin{array}{l}\text { Interview; } \\
\text { TALP }\end{array}$ & ContentAnalysis(ALCESTE) \\
\hline
\end{tabular}


only in biological, but also in psychosocial. Physical losses, psychological and social were identified by experienced them, being evidenced as biological aspects, the image of weakness and worsening, which culminate in hospital and death. As psychosocial aspects, was quoted sadness, pain, despair, contempt, loneliness, prejudice, social isolation, fear of discrimination, lack of work and prospects for future life $[4-6,13]$.

Despite recent advances regarding knowledge about AIDS and prolonging life expectancy, due to treatment with antiretroviral drugs, the disease arouses in society feeling of fear, persisting social representations of the disease, linked to discrimination and social prejudice, associating AIDS in old age risk group, embarrassment and shame, that is, there are still the initial representations of the disease [13-17].

The sense of shame pointed to by the elders can be explained by the image that emerged at the beginning of the AIDS epidemic in the minds of people as a disease associated with a punishment from God for having had a "promiscuous" behavior or considered outside the box, said the normal society [18].

It was appointed by the elderly living with HIV/ AIDS lack of trust by health professionals. The doctor was seen as a professional that does not bring to solving the initial problem, delaying the diagnosis, for not believing that the elder may be infected with HIV, worsening symptoms, often resulting in early death [4].

However, some elderly people on the first impact of news about the diagnosis of HIV, have surrounded feelings of anguish, despair and death wish, in order to put an end to suffering [5].

Elderly HIV-infected reported living with the constant imminence of death that centralizes all other representations about the disease and its treatment, causing great suffering by the uncertainty of survival, fear and despair [3-5].

A study found differences in social representations of HIVIAIDS in relation to schooling. For older people with low educational level, the representations were more negative aspects regarding the disease and its prognosis and for more education, there were more positives in the representations of disease, associated with hope and the possibility of treatment. What could be related to a greater knowledge of antiretroviral therapy by the people of their primary education, making them no longer see AIDS as a lethal disease to a manageable disease with the possibility of a better prognosis [3].

However, for some authors, even prevailing the negative image of the disease associated with stigma, biological image of the poor sick, cachectic and ugly, is being replaced by the image of a healthy person, due to advances in antiretroviral treatment [5].

\section{Agingand HIV/AIDS: a double challenge}

Go through the aging process with HIV/AIDS or acquire the virus during old age is represented by the elderly as a double challenge to face the situations experienced. Added to all the challenges that people with HIVIAIDS need to win the biopsychosocial level challenges faced also because they are elderly, since the social representations of aging may be associated with losses, limitations and unique medical and psychosocial needs of this age group and is therefore considered a double challenge to be an elderly person and be HIV positive [3-6].

Discrimination and prejudice in both situations always present in social relations: being HIV positive and being an elderly person. Thus, older people living with HIVIAIDS face discrimination and double bias. This prejudice makes these people be filled with fears before the exclusionary judgments and looks the other and seeks to protect from social isolation, fear of being discovered with HIV, resulting in loneliness. In many cases this reality experienced by older people with HIVIAIDS worsens, leading to cases of depression, when discrimina- 
tion and prejudice depart from family and friends themselves who should be running role of support and care $[3-5,13]$.

\section{HIVIAIDS the coping ways}

It was observed in the studies analyzed on the social representations of HIVIAIDS to HIV-positive elderly people who, even before the diagnosis, some people look for ways to cope with the disease desiring to live with quality, anchoring the hope, the need to fight, following the treatment prescribed and proper nutrition [3-6].

For some older people, the need to have a life equal to what it was before diagnosis, causes these face the disease with strict rules to prevent its progression, staring medical treatment, medications, changes in lifestyle as unique forms of survival, in order to improve their quality of life [6].

A study conducted with older people living with HIVIAIDS found that these people have overcome the difficulties before the aging process and the issues turning around the disease to position itself in society in terms of what they are and not the tax stereotype the double reality experienced by them [5].

For some older people, the HIV status for HIV did not change their lifestyle, being incorporated as a further aspect to be experienced. Even before some fears and difficulties of daily life and the disease itself, preserves the desire to live, to fight and enjoy life. These people seek to occupy their time with few distractions, building particular ways of dealing with HIVIAIDS [6].

The social representation of HIVIAIDS in some studies analyzed, is anchored in the figure of God as a way of coping, allowing endure suffering and frustration resulting from the disease, particularly the elderly and poorly educated people. Therefore religion and spirituality can be seen as a network of emotional support, improving health and quality of life of older people through elements such as faith and hope [3-5].
It was observed that there is a difference in the representations of the disease from the time of diagnosis, which can be explained by understanding that it can be influenced by experiences in everyday life, the interpersonal communications and its social construction. So for people with newly diagnosed, it was observed that the social representations of AIDS is associated with promiscuity, prejudice and guilt and for people with delayed diagnosis, the social representations are associated to conformity [3].

\section{Vulnerability to HIV/AIDS}

HIVIAIDS are still represented by older people as something distant from their realities. While most know the transmission and having unprotected sexual intercourse, these people do not consider themselves vulnerable to HIV infection. What can justify the increase in the number of cases of HIV/ AIDS in this age group [5].

The social representation of vulnerability to HIV/AIDS is anchored to the lack of protection and relationships considered promiscuous. Older people cannot answer how they acquired HIV, and older women trust their partners justifying non-use of condoms. These women are characterized as vulnerable to infection because they are at risk before the infidelity of their partners. And, most participants recognized the condom in order to prevent and report that made their use only in extramarital relations and with people not known $[5,17]$.

Therefore, it is observed that the social representations of HIVIAIDS developed by older people can explain their attitudes to risk behavior, sexual practices, prevention, treatment adherence, defense mechanisms, coping with the disease, denial and integration into society.

\section{Conclusion}

The analysis of scientific production about social representations of HIV/AIDS built by elderly showed 
that the beliefs, interpretations and network developed symbolizations are complex, permeated by the disease and its biopsychosocial consequences. However, it was observed that even with the complexity of the phenomenon experienced, people look for ways of coping with the aim of improving their quality of life and leave it as close as possible to what it was before the diagnosis.

From the understanding that the social representations guide the behavior of social actors in relation to the purpose, it was found that the majority of older people know how to prevent it, do not see themselves as vulnerable to HIV infection and end up adopting behaviors and risky sexual practices. Thus realize the importance of more effective educational and preventive actions directed to these people, with a multidisciplinary and intersectoral action, seeking to meet any problem involving the imagination of these people regarding the disease, reducing morbidity and mortality.

Thus, knowledge of social representations becomes relevant to guide the behaviors and interventions to improve the health of the people involved, also helping in the reconstruction of representations that highlight rights as a citizen and social inclusion, from a more positive view of case of illness, treatment and coping with the disease.

It is observed that it is necessary to carry out further studies on the subject of HIVIAIDS on the elderly population, as it has increased the number of elderly people afflicted with this disease, as well as the use of the theory of social representations has proven quite useful for understanding of various phenomena including the health field, for pointing out strategies for action and addressing the problems experienced by social groups.

\section{References}

1. Apratto Junior PC; Barros MBL; Daumas RP; Andrade MKN; Monteiro DLM; Vincent BRL et al. Trends in AIDS Incidence in Individuals Aged 50 Years or Older in the City of Rio de Janeiro, Brazil, 1982-2011: An Age-Period-Cohort Analysis. Int. J. Environ. Res. Public Health. 2014; 11(8): 7608-21. doi: 10.3390/ ijerph110807608

2. Freitas EV; Py L. Tratado de Geriatria e Gerontologia. 3 ed. Rio de Janeiro: Guanabara Koogan, 2011.

3. Saldanha AAW, Araújo LF, Sousa V. C. Envelhecer com Aids: representações, crenças e atitudes de idosos Soropositivos para o HIV. Revista Interamericana de Psicología/Interamerican Journal of Psychology. 2009; 43(2): 323-32. Available from: http://pepsic.bvsalud.org/scielo.php?pid=\$003496902009000200013\&script=sci_arttext

4. Brasileiro M, Freitas MIF. Representações sociais sobre Aids de pessoas acima de 50 anos de idade, infectadas pelo HIV. Rev. Latino-Am. Enfermagem. 2006; 14(5): 789-95. Available from: http://www.scielo.br/pdf/rlae/v14n5/pt v14n5a22.pdf.

5. Oliveira DC, Oliveira EG, Gomes AMT, Teotônio MC, Wolter RMCP. O significado do hiv/aids no processo de envelhecimento. Rev. enferm. UERJ. Rio de Janeiro. 2011; 19(3): 353-8. Available from: bireme.br/cgi-bin/wxislind.exe/iah/online

6. Lima RS, Oliveira EG, Oliveira DC, Tosoli AM, Santos EI. Os antirretrovirais no cotidiano de idosos soropositivos: um estudo a partir das representações sociais. R. pesq. Cuid.: cuid. fundam. online. 2010; 2(supl): 952-5. Available from: http://www.seer. unirio.br/index.php/cuidadofundamental/

7. Napper LE; Fisher DG; Reynolds GL. Development of the Perceived Risk of HIV Scale. AIDS Behav. 2012; 16: 1075-83. doi: 10.1007/s10461-011-0003-2.

8. Earnshaw VA; Smith LR;Chaudoir SR;Lee IC; Copenhaver MM. Stereotypes about people living with hiv: implications for perceptions of hiv risk and testing frequency among at-risk populations. AIDS Educ Prev. 2012; 24(6): 574-81. doi: 10.1521/ aeap.2012.24.6.574.

9. Jacquescoley E. Behavioral prevention study gauges HIVIAIDS and depression in the older US population. AIDS Care. October. 2008; 20(9): 1152-53. doi: 10.1080/09540120701842761.

10. Ilia L; Echenique M; Jean GS; Bustamante-Avellaneda V; Metsch $L$; Mendez-Mulet L et al. Project roadmap: reeducating older adults in maintaining aids prevention: a secondary intervention eor older hiv positive adults. AIDS EducationandPrevention, The Guilford Press. 2010; 22(2): 138-47. Available from: http://www. globalaging.org/health/us/2010/roadmap.pdf

11. Ferreira OGL. Representações Sociais sobre o Envelhecimento Ativo: um estudo com idosos independentes funcionalmente. 2008. [dissertação]João Pessoa: Universidade Federal da Paraíba/UFPB; 2008. 81 p. doi: http://dx.doi.org/10.1590/ $\underline{\text { s0080-62342010000400030 }}$ 
12. Torres CC, Bezerra VP, Pedroza AP, Silva LM, Rodrigues TP, Coutinho NJM. Representações Sociais do Hiv/Aids: buscando os sentidos construídos por idosos. R. pesq. Cuid.: cuid. fundam. online. Dez.2011; (5 supl): 121-8. Available from: bireme.br/cgibin/wxislind.exe/iah/online/

13. Moscovici S. O fenômeno das representações sociais. In: MOSCOVICl, S. Representações Sociais. Petrópolis - Rio de Janeiro: Vozes, 2003. p. 29-109.

14. Moscovici S. A representação social da psicanálise. Rio de Janeiro: Zahar, 1978.

15. Mendes KDS, Silveira RCCP, Galvão CM. Revisão Integrativa: método de pesquisa para a incorporação de evidências na saúde e na enfermagem. Texto Contexto Enferm. Florianópolis. 2008; 17(4): 758-64. $\quad$ http://dx.doi.org/10.1590/S0104$\underline{07072008000400018}$

16. Martins CRM, Camargo BV, Biasus F. Representações sociais do idoso e da velhice de diferentes faixas etárias. Universitas Psychologica. 2009; 8(3): 831-47. Available from: http://revistas. javeriana.edu.co/index.php/revPsycho/article/viewFile/627/388

17. Saldanha AA, Felix SMF, Araújo LF. Representações sobre a Aids na velhice por coordenadoras de grupos da terceira idade. Psico-USF. jan./jun. 2008; 13(1): 95-103. Available from: http:// www.scielo.br/pdf/pusf/v13n1/v13n1a12.pdf

18. Jodelet $D$. Representações sociais: Um domínio em expansão. In: JODELET, D. As representações sociais. Rio de Janeiro: Editora da Universidade do Estado do Rio de Janeiro, 2002. p. 17-44.

\section{Comment on this article:}

\section{f) $B$ in $8+S P$}

,

http://medicalia.org/
Where Doctors exchange clinical experiences, review their cases and share clinical knowledge. You can also access lots of medical publications for free. Join Now!

\section{Publish with iMedPub}

http://www.imed.pub

International Archives of Medicine is an open access journal publishing articles encompassing all aspects of medical science and clinical practice. IAM is considered a megajournal with independent sections on all areas of medicine. IAM is a really international journal with authors and board members from all around the world. The journal is widely indexed and classified Q1 in category Medicine. 